$R C .633$

GEOLOGICAL SURVEY CIRCULAR 633

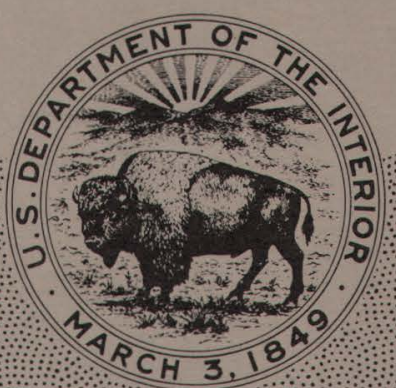

Standards for the

Classification of

Public Coal Lands 



\section{CONTENTS}

Abstract
Introduction
History
Purpose of classification
Present standards
Maximum depth
Maximum depth for coals of
minimum thickness
Use of as-received Btu values
Minimum heat value
Minimum thickness
Maximum thickness ...............................................
Thickness of coal beds containing partings.

Page
1
1
1
2
3
5
5
5
5
5
6
6

Present standards-Continued

Treatment of coal beds of irregular thickness

Treatment of a thin coal associated with a thick coal and treatment of a group of coal beds................................ 7

Burned coal ....................................................... 8

Quality ........................................................... 8

Diagram (fig. 1) showing depth limits of coals... 8

Areal basis for classification................................. 9

Summary of the standards for the

classification of public coal lands..................... 9

References cited .............................................. 10

\section{ILLUSTRATIONS}

FiguRE 1. Diagram showing depth limits of coals of different Btu (as-received basis) and of different thicknesses less than 6 feet.

2. Diagram showing split or broken beds and their value for classification 



\title{
Standards for the Classification of Public Coal Lands
}

\author{
By N. Wood Bass, Henry L. Smith, and George H. Horn
}

\begin{abstract}
In order to provide uniformity in the classification of coal lands in the public domain, certain standards have been prepared from time to time by the U.S. Geological Survey. The controlling factors are the depth, quality, and thickness of the coal beds. The first regulations were issued April 8, 1907; others followed in 1908, 1909, and 1913. Except for minor changes in 1959, the regulations of 1913, which were described in U.S. Geological Survey Bulletin 537, have been the guiding principles for coal-land classification. Changes made herein from the standards previously used are: (1) a maximum depth of 6,000 feet instead of 5,000 feet, (2) a maximum depth of 1,000 feet instead of 500 feet for coals of minimum thickness, (3) use of Btu (British thermal unit) values for as-received coal instead of air-dried, and (4) a minimum Btu value of 4,000 for as-received coal instead of 8,000 for air-dried. An additional modification is that the maximum thickness of 8 feet which was designated in the Classification Chart for Coal Lands in 1959 is changed to 6 feet. The effect of these changes will be the classification of a greater amount of the withdrawn land as coal land than was done under earlier regulations.
\end{abstract}

\section{INTRODUGTION}

The purpose of this report is to set forth certain changes in the standards for determining what lands in the public domain are classifiable as coal lands. The controlling factors in determining what lands are coal lands are the depth, quality, and thickness of the coal beds. Changes made from the standards previously used (Smith and others, 1913) are: (1) a maximum depth of 6,000 feet instead of 5,000 feet, (2) a maximum depth of 1,000 feet instead of 500 feet for coals of minimum thickness, (3) use of Btu (British thermal unit) values for as-received coal instead of air-dried, and (4) a minimum Btu value of 4,000 on an as-received basis instead of 8,000 on an air-dried basis. An additional modification is that the maximum thickness of 8 feet which was used in a Classification Chart for Coal Lands (U.S. Geological Survey unpub. chart, approved by Acting Director, Sept. 9,
1959) is changed to 6 feet. The effect of these changes will be the classification of a greater amount of the withdrawn land as coal land than was done under earlier regulations. A minimum thickness of 14 inches for coals yielding 12,000 Btu or more, which has been in effect for almost 60 years, is not changed. The minimum thickness for coals of lesser Btu values is increased at specified rates.

Many geologists of the U.S. Geological Survey have contributed to the preparation of this report.

\section{HISTORY1}

Prior to May 20, 1862, when the Homestead Act was passed by Congress, lands of the public domain were sold by the Federal Government and thus constituted a source of national revenue. Upon passage of the Homestead Act, the national policy became the promotion of settlement and the development of the publis domain. The mineral land laws, enacted by Congress mainly between 1865 and 1875 , had as their purpose the promotion of mineral development on the public domain. These laws were based on local mining customs in force in the mining camps of that time. The act of May 10, 1872, provided for the exploration and purchase of mineral land on the public domain; it clearly was written to embrace metalliferous minerals, both lode and placer, for these were the mineral deposits known and sought at that time. From time to time in later years Congress authorized the acquisition under the placer laws of nonmetalliferous minerals, which included petroleum, salines, and building stone.

Public lands containing coal were $c$ salt with by separate acts of Congress. The act of March 3,1873 , provided for the purchase of coal land on the public domain at $\$ 10$ an acre if the land

1 Most of the history and many other parts of this report were obtained from Smith and others (1913). 
was more than 15 miles from a railroad and at $\$ 20$ an acre if the land was within 15 miles of a railroad. An individual was limited to 160 acres, an association of persons might acquire 320 acres, and an association of four or more persons who had opened and improved a coal mine at a cost of more than $\$ 5,000$ could purchase an area of 640 acres.

Although it was not specifically stated, it is apparent from the language used in the many public land laws that the intent of Congress was to dispose of tracts in the public domain for whatever use they were best suited. For example, the Homestead Act stipulated “***nor shall any mineral lands be liable to entry and settlement." As early as $\mathbf{1 7 8 5}$ the Continental Congress stipulated that each State entering the Union would be granted a part of each township for schools. Ohio, the first State admitted to the Union (April 30, 1802), was allotted sec. 16 of each township. Later, other States were granted secs. 16 and 36, and a few States, secs. 2, 16, 32, and 36. The lands so granted were to be nonmineral, and wherever the stipulated sections were not available, the State was allowed to select other tracts in lieu of the allotted sections, but such tracts were to be nonmineral. Beginning on July 1, 1862, the railroad grants made by Congress to corporations to build railroads stipulated that the railroad corporations were to receive every alternate section of land in belts ranging in width from 20 to 40 miles on each side of the railroad; these sections were to include only nonmineral land, except for coal and iron land.

Congress stipulated in the act of March 3, 1879, which created the U.S. Geological Survey, that the Director of the Survey should classify the public lands. Except, however, for withdrawals of public lands for inclusion in reclamation projects and the segregation of reservoir sites, the classifications of land by the Geological Survey during the first 25 years of its existence were broadly based to identify features pertaining to land values for many purposes. President Roosevelt in 1906 directed the Secretary of the Interior to immediately withdraw from entry all valuable coal lands on the public domain. The Geological Survey, on the basis of its mass of scientific information on the public domain, prepared a list of public lands which had a reasonable probability of containing valu- able coal, and these lands were promptly withdrawn from entry. Some additions were made to the withdrawals during the next few years. It was not until June 25, 1910 (30 S at. 847), however, that Congress passed the withdrawal act, although the earlier withdrawals had been in force since 1906. The Geological Survey, beginning in 1906 upon instructions from the Secretary of the Interior, was engaged in examining the withdrawn lands, and on the basis of these investigations the lands were classified; the lands found to be noncoal were restored to entry, those found to contain worlable coal beds were appraised and priced at varying amounts per acre.

Inasmuch as the lands withd"awn included some lands that were valuable for farming, Congress later passed laws known as the "Separation Acts"- the act of March 3, 1909 (35 Stat. 644) and the act of June 22, 1910 (36 Stat. 583) - which provided for a separation of the surface rights and the mineral rights and allowed the land claimant to obtain patent to his land by reserving to the United States tre coal deposits and the right to prospect and mine them.

The Mineral Leasing Act of February 25, 1920 (41 Stat. 407) provided for the leasing of coal and other mineral lands on the public domain and ended the practice of disposing of coal lands at appraised values. Under the provisions of the Mineral Leasing Act a permit to explore public land for coal may be obtained, or, if the land is known to contain workable coal, it is subject to competitive bidding for a lease. The operator is required to pay the Federal Government a stipulated royalty per tor of coal mined and an annual rental for the land held under lease.

During the four decades following the passage of the Leasing Act, the geclogic examination and classification of withdrawn lands continued at a reduced rate. In 1960, however, an accelerated program of examination and classification of lands withdrawn for leasable minerals was begun.

\section{PURPOSE OF CLASSIFICATION}

In order to provide uniformity to executive action in the classification of cosl lands in the public domain, certain standards for determining what lands are coal lands lave been prepared from time to time by the Geological Sur- 
vey. It is the duty of the Geological Survey to determine what lands are underlain by coal within the limits set by these classification standards. Field examination to determine the presence of coal, thickness of beds, quality, attitude, depth, and other factors about the coal should precede classification. The field data should be assembled in such a form, including legible maps on adequate scale, as to facilitate the work of classification. Classification involves the consideration of all known geologic facts to determine what legal subdivisions of lands are coal lands under the provisions of the standards.

The first guiding regulations for the classification and valuation of public coal lands, approved by the Secretary of the Interior, April 8, 1907 , prescribed a minimum workable thickness of coal of 2 feet and a maximum workable depth of 1,500 feet for coal land; all investigated lands that contained coal beds of less thickness or at greater depth were classified as noncoal. New regulations of April 15, 1908, retained the minimum thickness of 2 feet and prescribed a maximum depth of 3,000 feet for high-grade coal and 2,000 feet for certain thicknesses of lowgrade bituminous and subbituminous coal. On April 10, 1909, the Secretary of the Interior approved regulations which fixed a minimum thickness of 14 inches and retained the maximum depth of 3,000 feet; the heating value of unweathered coal and the tonnage of coal underlying the land were factors used in the classification. About 4 years later the following regulations were approved on February 20, 1913, by the Secretary of the Interior (Smith and others, 1913, p. 96):

1. Land shall be classified as coal land if it contains coal having:

(a) A heat value of not less than $8,000 \mathrm{Btu}$ on an air-dried, unwashed or washed, unweathered mine sample.

(b) A thickness of or equivalent to 14 inches for coals having a heat value of $12,000 \mathrm{Btu}$ or more, increasing 1 inch for a decrease from 12,000 to $11,000 \mathrm{Btu}, 1$ inch for a decrease from 11,000 to $10,500 \mathrm{Btu}, 1$ inch for each decrease of 250 Btu from 10,500 to 10,000 , and 1 inch for each decrease of $100 \mathrm{Btu}$ below 10,000 .

(c) A depth below the surface for a bed of coal 6 feet or more thick of not more than 100 feet for each 300 Btu or major fraction thereof, and for a bed of minimum thickness for that coal a depth of not more than 500 feet, and for beds of any thick- ness between the minimum and 6 feet a depth directly proportional to that thickness within these limits, provided that, if the coal lies below the depth limit but within a horizontal distance fror the surface not exceeding 10 times the depth limit, or if its horizontal distance from the foot of a possible shaft (not deeper than the depth limit) plus 7.5 times the depth of such shaft does not exceed 10 times the depth limit, the land shall be clessified as coal land; provided, further, that the depth limit shall be computed for each individual bed, except that where twc or more beds occur in such relations that they may be mined from the same opening, the depth limit may be determined on the group as a unit, being fixed at the center of weight of the group, no coal that is below the depth limit thus determined to be considered.

2. Classification shall be made by quarter-qu>rter sections or surveyed lots, except that for gond reason classification may be made by $21 / 2$-acre tracts or multiples thereof described as minor subdivisions of quarter-quarter sections or rectangular lotted tracts.

Detailed stipulations for appraisal ir dollars per acre of the coal lands were set forth in the regulations. They provided also that, after the valuation and the classification were made, the lands should be restored to entry. After restoration, the coal lands could be acquired at the appraised prices and the noncoal land should revert to the status which they had prior to the withdrawal.

A new set of standards for the classification of coal lands was approved by the Acting Director of the Geological Survey on September 9, 1959. The principal deviation from the regulations of February 20, 1913, was a change from 6 to 8 feet for the maximum thickness of a bed of coal. It is apparent, however, that a 6-footthick gently dipping coal bed can be classified to a greater depth by using the 1913 reg'xlations (Smith and others, fig. 3) rather than the 1959 standards. The belt of land lying betwe?n these two depth limit lines would be classified as noncoal if the 8-foot maximum thickness is used but would be classified as coal land if th? 6-foot maximum thickness is used.

\section{PRESENT STANDARDS}

The standards herein described for the classification of coal lands provide for (1) a maximum depth of 6,000 feet, (2) a maximum depth of 1,000 feet for coals of minimum trickness, 
(3) use of Btu values for as-received coal, (4) a minimum heat value of $4,000 \mathrm{Btu},(5)$ a minimum thickness of 14 inches for all coals that have a heat value of $12,000 \mathrm{Btu}$ or more, and (6) a maximum thickness of 6 feet for a coal bed that has a thickness of $\mathbf{6}$ feet or more (fig. 1).

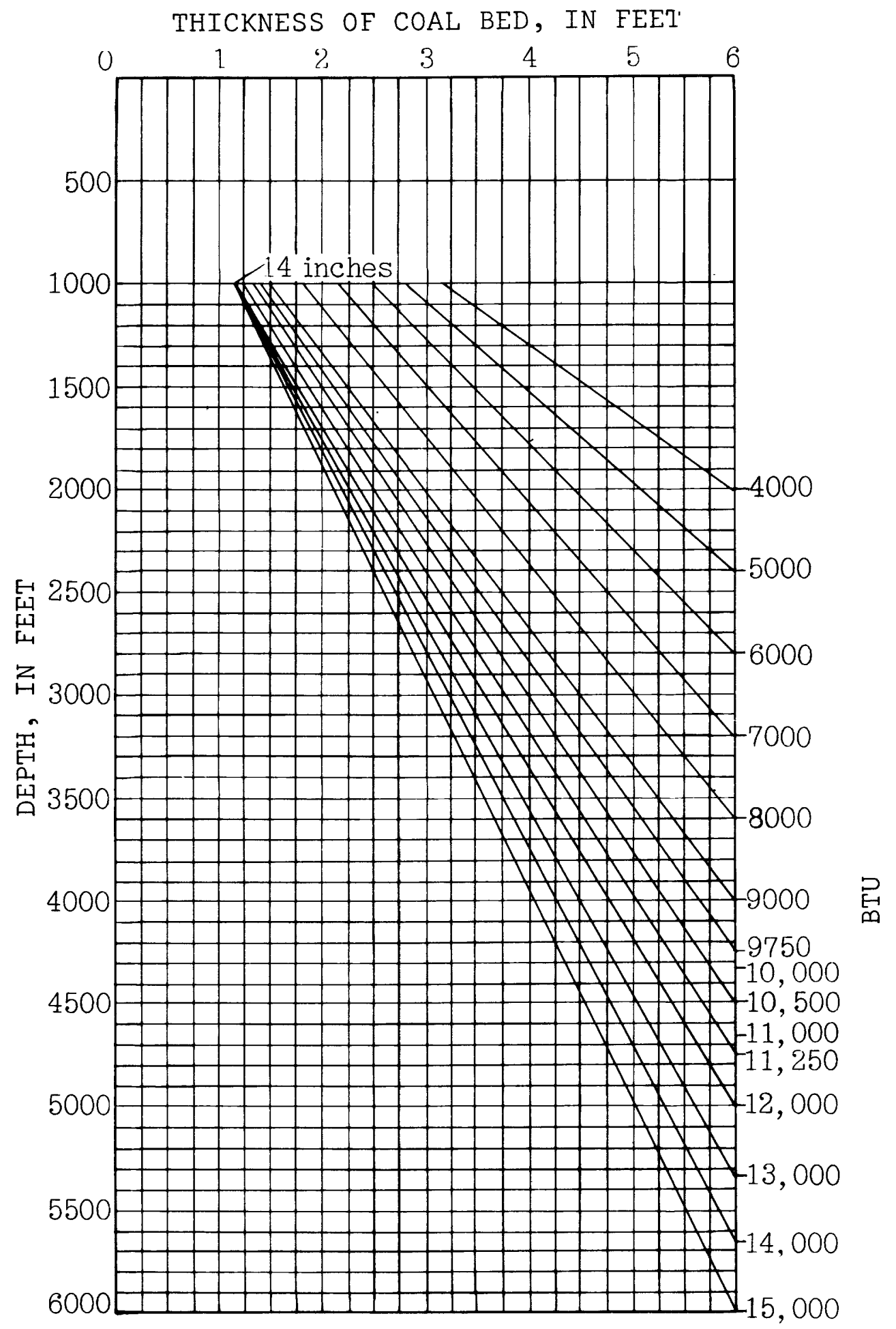

FIGURE 1.-Diagram showing depth limits of coals of different Btu (as-received bas:s) and of different thicknesses less than 6 feet. 


\section{MAXIMUM DEPTH}

Smith and others $(1913$, p. 75) fixed a maximum depth of 5,000 feet for a coal that has an air-dried heat value of $15,000 \mathrm{Btu}$. They assumed for classification purposes "that a coal 6 feet or more thick is workable to a depth of 100 feet for each $300 \mathrm{Btu}$ it contains." A maximum depth of 6,000 feet, which is 1,000 feet greater than the maximum prescribed in earlier regulations, is designated in the present standards because the advance in mining technology since 1913 appears to warrant the use of a greater maximum depth. Recent investigations of possible in situ exploitation of coal, if developed to a point where such operations are economic, may make a depth of 6,000 feet obsolete in the near future.

\section{MAXIMUM DEPTH FOR COALS OF MINIMUM THICKNESS}

A large increase in the mining of coal by stripping has taken place, particularly in recent years, since the regulations of 1913 were issued. The depth to which strip mining can be carried on economically has increased as machines and techniques have improved. Although the maximum depth of 500 feet prescribed in 1913 for coal of minimum thickness (Smith and others, 1913, p. 75) is adequate for present operations, a depth of 1,000 feet may be more realistic for the future. Moreover, the change to 1,000 feet will make the classification of coal lands conform more closely to the data on coal reserves published from time to time by the U.S. Geological Survey (Averitt, 1969). The selection of 1,000 feet as the maximum depth for coals of minimum thickness is particularly important in the lignite fields of North Dakota. Brant (1953) stated that, except for some buttes in the southwestern part of the State where the lignite beds are at a depth between 1,000 and 1,200 feet, all minable lignite is at a depth of less than 1,000 feet. Most of these buttes, moreover, are in an area that was classified as coal land many years ago. Inasmuch as the greatest part of the resources of lignite and subbituminous $C$ coal is in nearly flat-lying surface formations in the Dakotas, eastern Montana, and northeastern Wyoming, it is almost entirely at a depth of less than 1,000 feet.

Any land that contains a coal bed of the minimum thickness specified for its particular Btu value shall be classified as coal land for depths ranging between 0 and 1,000 feet.

\section{USE OF AS-RECEIVED BTU VALUF:}

The rules for classification are modified herein to the extent that heat values for asreceived coal shall be used instead of values for air-dried coal as in the past, because of the conditions in the laboratory where the analyses of coal are made. These conditions are described under the heading "Quality."

In order to make this changeover without causing large changes in the depth limits for coals of various heat values, a comparison between air-dried and as-received Btu values of about 450 analyses of bituminous, sibbituminous, and lignite coals was made. It was found that subbituminous $B$ coal whose air-dried heat value is about $10,000 \mathrm{Btu}$ has an as-rec sived heat value of about 9,000 Btu. The comparison of coals of lower rank showed somewhat erratic differences, but comparison of coals whose heat value is more than $9,000 \mathrm{Btu}$ showed the difference to diminish fairly uniformly between 9,000 and $15,000 \mathrm{Btu}$. Accordingly, the spacing for the Btu scale in figure 1 between 9,000 and 15,000 $\mathrm{Btu}$ is uniform at 333 feet per $1,00 \mathrm{C} \mathrm{Btu}$; between 9,000 and 4,000 the spacing is 400 feet per $1,000 \mathrm{Btu}$. Although these two uniform sets of spacing do not agree precisely with the comparisons between the two scales that were made with large groups of analyses, they do not deviate from them by a great amount and they have the merits of simplicity and uniformity.

\section{MINIMUM HEAT VALUE}

The regulations for classification of coal land approved on February 20, 1913 (\$mith and others, 1913) stipulated that any coal of proper thickness and depth that has an air-dried heat value of $8,000 \mathrm{Btu}$ or more is considered workable and that land containing such coal is to be classified as coal land. Advances in cral beneficiation and in the designs of steam plants since 1913, however, have made possible the commercial use of coal that has a much lower Btu value. Accordingly, it is considered advisablo to lower the minimum Btu requirement for classification purposes to $4,000 \mathrm{Btu}$ on an as-received basis (fig. 1).

\section{MINIMUM THICKNESS}

An investigation of the commercial mining of coal beds of various thicknesses was made in connection with the preparation of the regulations promulgated in 1913 (Smith and others, 1913, p. 69). It was found that the ccst of min- 
ing coals less than 6 feet thick increases as the thickness decreases, that coals yielding 10,000 Btu were being worked "down to a thickness of 18 or 19 inches," that coals yielding $12,000 \mathrm{Btu}$ were being worked "down to 14 or 15 inches," and that better coals were being mined from even thinner beds. In the light of these findings, a minimum thickness of 14 inches was fixed by Smith and others (1913) for all coals having $12,000 \mathrm{Btu}$ or more (air-dried basis), the minimum increasing 1 inch for a decrease from 12,000 to $11,000 \mathrm{Btu}, 1$ inch for a decrease from 11,000 to $10,500 \mathrm{Btu}, 1$ inch for each decrease of $250 \mathrm{Btu}$ from 10,500 to $10,000 \mathrm{Btu}$, and 1 inch for each decrease of $100 \mathrm{Btu}$ below 10,000 Btu.

The minimum thickness of 14 inches is retained in the present standards; thus, the standards provide for a minimum thickness of 14 inches for all coals having 12,000 Btu or more (as-received basis), the minimum increasing 1 inch for each decrease of $750 \mathrm{Btu}$ between 12,000 and 9,000 Btu, and increasing 1 inch for each decrease of $250 \mathrm{Btu}$ between 9,000 and 4,000 Btu.

In the classification of lands that contain beds of lignite in North Dakota, South Dakota, and eastern Montana, the practice of the Geological Survey has been to use a minimum thickness of 2 feet 6 inches even though the heat value of the lignite varies rather widely throughout the region. Accordingly, in the present standards a minimum thickness of 2 feet 6 inches is fixed for a lignite that has an as-received heat value of $6,000 \mathrm{Btu}$. Inasmuch as the minimum thickness of a coal that has a Btu value of 9,000 is fixed at 1 foot 6 inches, which corresponds to the minimum thickness designated by Smith and others (1913, fig. 3) for the equivalent 10,000 Btu (airdried basis), the minimum thickness for coals whose heat value ranges between 9,000 and 6,000 $\mathrm{Btu}$ (as-received basis) is increased 1 inch for each reduction of $250 \mathrm{Btu}$. Moreover, this same scale is extended to coals whose heat value ranges between 4,000 and 6,000 Btu (as-received basis).

\section{MAXIMUM THICKNESS}

The investigation conducted by Smith and others (1913, p. 74-75) of the cost of mining thick and thin beds of coal showed that there is little difference in the cost per ton for mining beds of coal 6 feet thick and those 10 feet thick or thicker. Accordingly, a maximum thickness of 6 feet was fixed in the regulations of 1913 and is retained in the present standards. Any bed whose thickness is more than 6 feet is treated as a 6-foot bed.

\section{THICKNESS OF COAL BEDS CONTAININF PARTINGS}

Coal beds that include partings have been treated uniformly by the Geological Survey for many years, as prescribed by Smith and others (1913, p. 70-71) after they had ccnducted an investigation. They concluded that any parting of bone or impure coal detracted from the value of the coal an amount equal to the thickness of the parting. Two coal benches, each workable, are treated as parts of a single bed if the thickness of each bench exceeds the parting between them and the parting does not exce? $31 / 2$ feet. Two thick benches of coal are trested as two beds if the thickness of the parting between them exceeds the thickness of either one. A bed of coal 36 inches thick that includes a parting 6 inches thick is regarded as being equivalent to a solid bed 24 inches thick. The thickness of the parting is deducted from the thirner of the adjacent benches above and below it. To calculate the total thickness of a coal bed, start with the best bench and add the thickness of the next bench above or below it after deducting from the coal bench a thickness equal to tl $\circ$ thickness of the intermediate parting, and continue through the entire coal unit. If a parting is thicker than the thinner adjoining coal bench, that bench is considered as having nc value. This practice is best illustrated by a group of concrete examples. (See fig. 2.)

\section{TREATMENT OF COAL BEDS OF IRREGULAR THICKNESS}

As pointed out by Smith and others (1913, p. 72), the determination of the probable limits of workability of a coal bed that varies in thickness from place to place is difficult. A few beds of coal may maintain a nearly uniform thickness over an area of several townships. In general, however, the thickness of most coal beds varies widely and within short distances. The rules described by Smith and others (1913, p. 72-73) and quoted below are followed in the present standards.

The simplest problem is that in which two unequal measurements on a single bed, taken at different places, are available. All such beds are assumed to grade uniformly in thickness from the thicker measurement to or 
through the thinner measurement, and a liniit to the workable coal is thus fixed that, while it may or may not agree with the unknown facts, is the most probable limit. In general, a coal bed that can be traced continuously along the face of a cliff, as can many beds in the West, has usually been assumed to extend under the land back from the cliff at least one-half the length of the cliff outcrop, the lens or bed having the shape of a half-circle, the length of the cliff outcrop being the diameter of the circle. Obviously, if the outcrop runs along the cliff for many miles, the extension of the coal back from the outcrop may be modified by many other factors, such as limit of depth, or outcrop on the opposite side of the hill. If the bed outcrops along the cliff with irregular thickness, only a moderate extension of the bed behind the cliff is assumed, the estimate being based on the character of the irregularities shown by measurements made along the cliff, or by a general knowledge of the extent of the lenses of that particular coal or of coals of that

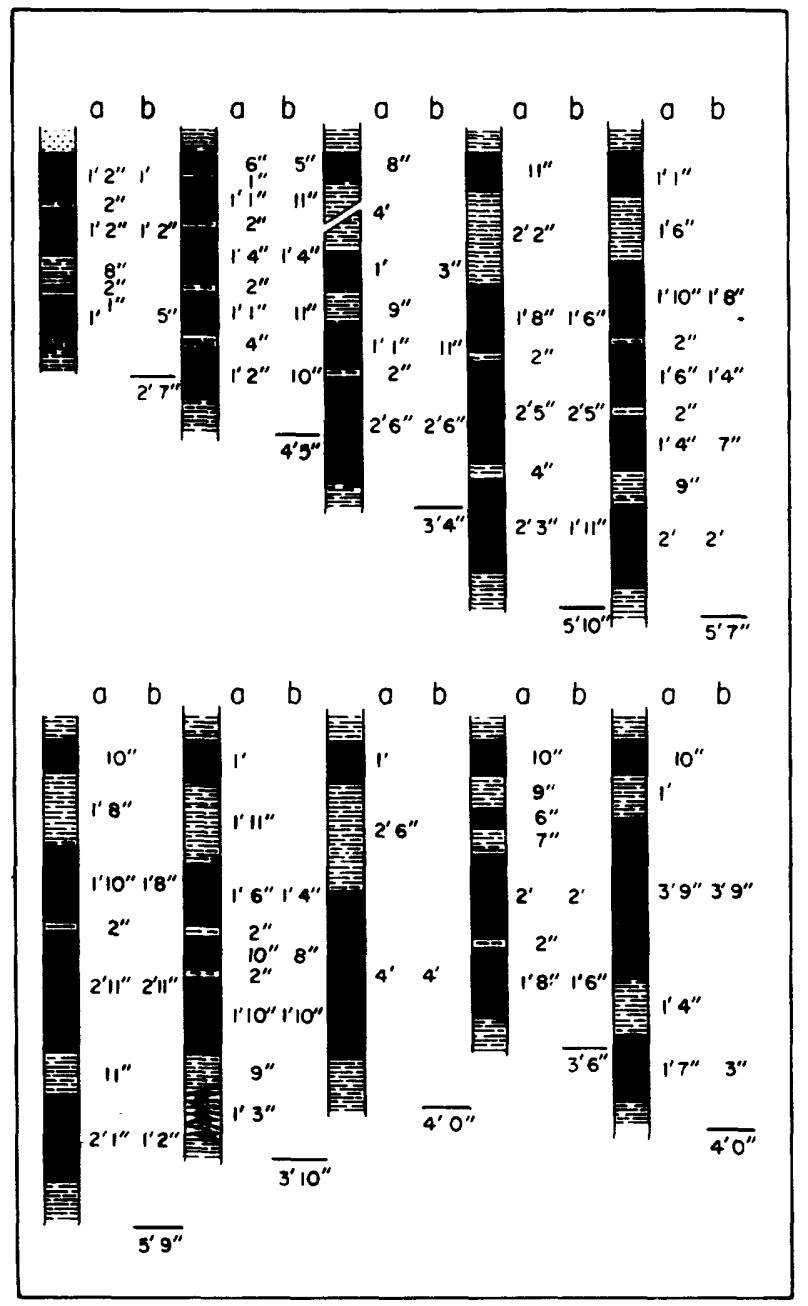

Figure 2.-Diagram showing split or broken beds and their value for classification: a, measured thickness; b, equivalent thickness used in classification and valuation. From Smith and others (1913, fig. 2). group, and depending on the general "habit" of the bed, if known, and also taking into account all local features. If the exposed outcrop does not extend in a straight line but, as is more common, runs in and out of revines, careful note is made of the thickening or thinning of the coal between one point of measurement and another in order to detect, if possible, any general tendency of the bed to thicken or thin in any direction, and all these measurements and tendencies are taken into account in determining the probable extent of the lens in ary direction.

Many beds studied are known to be of less than workable thickness in larger or smaller part, and any measurement showing a workable thickness on such a bed must usually be considered as a measure taken at the center of a small lens of workable coal. A discovery or measurement of a coal bed by a well, or by drilling, will have the same value as an isolated measurement on the outcrop. The content and shape to be assigned to any lens must depend on conditions and are largely matters of judgment, and such assignments or determinations especially require a wide knowledge of coals and of the particular group of coals to which the bed under consideration may belong.

Smith and others (1913) laid down explicit rules for treatment of special situations, such as groups of coal beds, coal beds in rugged terrain, and coal beds adjacent to a shaft. Inasmuch as these rules are not changed in the new standards, they are quoted herein.

\section{TREATMENT OF A THIN COAL ASSOCIATED WITH A THICK COAL AND TREATMEN'T OF A GROUP OF COAL BEDS}

The following material is quoted from Smith and others (1913, p. 75-77).

In general the limit of depth at which a coal bed may be profitably mined depends entirely upon the thickness of the bed and the quality of the coal. If, however, a thin but workable bed that lies below its ordinary minable depth is overlain by a thicker bed that lies within its own minable depth, the lower thin bed may, perhaps, be profitably worked by extending downward the shaft sunk to the higher, thicker coal, whereas the thinner bed could not have been profitably mined alone. A single shaft may also give access to all the coals of a group, and, though the cost of raising all the coal will be the same as if the coal were taken from a single bed, the cost of the shaft and the interest on that cost will be borne by the proceeds of a larger product. In some places the whole cost of a shaft may be borne by the coal of a thick bed that underlies seviral thinner beds or that lies in the middle of a grour of thinner beds. It is clear that no two shafts that penetrate groups of coal beds will present similiar conditions. The coals of such groups will vary in number from tv'o to twenty or more and may be included in an interral of 50 to 500 feet or more. Every case involving such conditions must be considered on its merits, ard here again the Geological Survey has found it necessary to establish a series of general precedents in order to make its treatment of such cases reasonably uniform. In some places 
it has been found possible to treat a group of coal beds as if they were all gathered at a "center of weight"that is, at a point determined by multiplying the computed thickness of each bed by its depth from the surface and dividing the sum of the products by the sum of the compensated thicknesses, the thicknesses of the various beds being reduced for partings in the manner already described.

\section{BURNED COAL}

Coal is commonly burned along the outcrop in most coal fields in the Western States. Because burning bakes and hardens rocks overlying coal, ledges of baked rock in many shades of red and orange are characteristic features of the western coal fields. Commonly, the baked rock is less than 50 feet thick, but in places it is several hundred feet thick. The extent of burned coal back from the outcrop is believed to be indicated by the width of the band of reddened rock and soil; its width may be only a few hundred feet where the slope above the coal is steep and the cover is great, but its width may be one-quarter to one-half of a mile or more where the overburden is thin. The coal may be destroyed by burning where it lies near the tops of buttes and mesas. Characteristically, the band of burned rock is wide on narrow divides and narrow or absent in gulches. In fact, unburned coal commonly crops out in the troughs of gulches where they intersect the horizon of the coal bed. The field geologist should indicate the extent of the burned coal by appropriate symbols on his map. In classifying the land the edge of the coal is assumed to coincide with the boundary line for the burned areas.

\section{QUALITY}

The heat value of air-dried coal as expressed in British thermal units has long been used as a basis for determining the quality of coal for coal-land classification. As stated by Smith and others $(1913$, p. 68-69), coals that contain large percentages of mineral matter and moisture, which are the noncombustible constituents, show correspondingly lower heat values as expressed in Btu. On the other hand, coals that have small percentages of mineral matter and moisture contain large percentages of the combustible constituents in coal and therefore yield high heat values. It was these facts that caused the geologists who prepared the regulations of 1913 to stipulate a minimum value in Btu for coal in the land to qualify it as coal land rather than to set a maximum percentage of mineral matter and moisture in the coal as a determining factor.

The rules for determining the minimum heat value of any coal considered for classification of the land and the depth limits of coals of different heat values and different thicknesses have been based in the past on Btu values on an airdried basis. Chemists of the U.S. Bureau of Mines who make the analyses have pointed out, however, that heat values on an as-received basis more nearly represent the true condition of the coal in the ground; furthermore, they are more suitable for making comparisons of coals of different rank. The Bureau of Mines discontinued reporting the analyses for the air-dried category many years ago because, according to R. F. Abernethy of the Bureau of Mines (written commun. to A. F. Bateman, Jr., U.S. Geological Survey, Jan. 3, 1961),

The air-dry step in the preparation of a sample for the laboratory is an intermediate operatios and can vary over quite a range. Samples of coal air-dried in winter may lose 5 to 8 percent more moisture than the same samples air-dried in the summer. This is due to the relative humidity of the air used in drying. The extremes in this laboratory run from $0^{\circ} \mathrm{F}$ air heatec to $86^{\circ} \mathrm{F}$ in the winter time to air at $90^{\circ} \mathrm{F}$ and $90-100$ percent relative humidity in the summer. The variation of the Btu on samples air dried under the above conditions would be so great they could not be compared.

\section{DIAGRAM (FIG. 1) SHOWING DEPTH LIMITS OF COALS}

The diagram, figure 1 , was constructed to conform as closely as possible to the earlier diagrams and yet to incorporate the changeover from air-dried to as-received Btu values. First, the diagram, figure 3 of Smith and others (1913, p. 76), was modified to incorporate a maximum depth of 6,000 feet. As modified, the figure of $10,000 \mathrm{Btu}$ (air-dried basis) coincides with the 4,000-foot depth line. A compilation of the airdried and as-received Btu values for about 450 analyses of western coals showed that coals that have an average air-dried value of $10,000 \mathrm{Btu}$ have an as-received value of $9,000 \mathrm{Btu}$. Accordingly, the 9,000-Btu figure was placed in figure 1 at the 4,000-foot depth line. Tro 15,000-Btu figure was placed at the 6,000-fort depth line, and the 2,000-foot interval betwe n the 4,000and 6,000-foot depths was divided into six equal intercepts, each of which represents a heat increment of $1,000 \mathrm{Btu}$. Thus, each increment of $1,000 \mathrm{Btu}$ represents a depth change of 333 feet. 
The comparison of air-dried and as-received heat values for 450 analyses of western coals, referred to above, showed a more erratic distribution of values for coals that had heat values less than 10,000 Btu on an air-dried basis and 9,000 Btu on an as-received basis, presumably because of the higher moisture content of these coals, which in turn gave less uniform values when the coals were air dried in the laboratory. If the as-received values were to be placed on the diagram scale at the precise positions that correspond with the air-dried Btu values determined by the study of 450 analyses, the intercepts between 6,000 and 9,000 Btu would range between 180 and 340 feet on the depth scale and the intercepts for Btu values less than $6,000 \mathrm{Btu}$ would have a much greater interval. It seems more sensible to apply a uniform scale to the Btu values for a diagram such as figure 1 rather than to plot irregular intervals based on comparisons of available analyses. The deviation from the actual value will not be large for any group of coals. Accordingly, as drawn, an increment of 1,000 Btu between 4,000 and 9,000 Btu represents a depth change of 400 feet.

As explained under the heading "Minimum thickness," the diagonal line that extends upward from the 6,000 Btu point terminates at 2 feet 6 inches because this thickness corresponds with the commonly used thickness cutoff for lignite that has low heat values. Thus, the difference in minimum thickness for coals whose heat values range between 6,000 and 9,000 Btu is 4 inches for each $1,000 \mathrm{Btu}$, or 1 inch for each $250 \mathrm{Btu}$. This scale is extended through the interval between 6,000 and 4,000 Btu.

The user of figure 1 should (1) obtain the asreceived $\mathrm{Btu}$ value from chemical analyses of unweathered mine samples of the coal, (2) plot this Btu figure on the scale at the right margin of figure 1, (3) draw a diagonal line upward to the 1,000-foot depth line to determine the minimum thickness for the coal, and (4) if the coal is thicker than the minimum thickness, read the depth limit at the intersection of the diagonal line and the vertical thickness line. For example, an 8,000-Btu coal has a minimum thickness of 1 foot 10 inches. All land that contains this coal bed at depths between 0 and 1,000 feet should be classified as coal land. If the coal bed is 4 feet thick, its depth limit is 2,360 feet instead of 1,000 feet; if its thickness is 6 feet or more, its depth limit is 3,600 feet. Another example is a coal bed that has an as-received Btu value of 5, ( $) 0$; if the bed is 2 feet 10 inches thick and at dopths between 1 and 1,000 feet, the land containing it should be classified as coal land. On the other hand, if the coal bed is less than 2 feet 10 inches thick, the land should be classified as noncoal.

\section{AREAL BASIS FOR CLASSIFICATION}

Classification shall be made by quarterquarter section (40 acres), surveyed tract, or surveyed lot.

\section{SUMMARY OF THE STANDARDS FOR THE} CLASSIFICATION OF PUBLIC COAI, LANDS

1. Land shall be classified as coal land if it contains coal having:

(a) A heat value of not less than 4,000 Btu (as-received basis) for an unwashed or washed, unweathered mine sample.

(b) A thickness of 14 inches for coals having a heat value of $12,000 \mathrm{Btu}$ or more (as-received basis), increasing 1 inch for each decrease of $750 \mathrm{Btu}$ between 12,000 and 9,000 Btu, and 1 inch for each decrease of $250 \mathrm{Btu}$ between 9,000 and 4,000 Btu. Any coal kad whose thickness is more than 6 feet is treated as a 6-foot bed. In calculating the thickness of a coal bed that contains partings of shale, bone, or impure coal, the thickness of the thinner bench of coal directly above or below the parting is reduced by the thickness of the parting; thus, the total thickness of the coal bed (including partings) is reduced by twice the tctal thickness of the partings.

(c) A depth of not more than 6000 feet for a bed of coal 6 or more feet thick having an as-received heat value of $15,000 \mathrm{Btu}$. The depth decreases 333 feet for each decrease of $1,000 \mathrm{Btu}$ between 15,000 and $9,000 \mathrm{Btu}$ and decreases 400 feet for each decrease of 1,00 ? Btu between 9,000 and 4,000 $\mathrm{B}^{+} \mathrm{u}$. For a bed of minimum thickness, the depth may not be more than 1,000 feet. For beds of any thick- 
ness between the minimum and 6 feet, the depth is graduated between 1,000 feet and the maximum depth for a 6-foot bed. Moreover, the depth limit shall be computed for each individual bed except that, where two or more beds occur in such relations that they may be mined from the same opening, the depth limit may be determined on the group as a unit and is fixed at the center of weight of the group; no coal below the depth limit thus determined is to be considered.

2. Classification shall be made by quarterquarter section, surveyed tract, or surveyed lot.

\section{REFERENCES CITED}

Averitt, Paul, 1969, Coal resources of the United States, January 1, 1967: U.S. Geol. Survey Bull. 1275, $116 \mathrm{p}$.

Brant, R. A., 1953, Lignite resources of North Dakota: U.S. Geol. Survey Circ. 226, 78 p.

Smith, G. O., and others, 1913, The classification of the public lands: U.S. Geol. Survey Bull. 537, 197 p. 


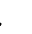

